\title{
38. Preliminary Notes on the Development of Geotelphusa dehaani (White).
}

\author{
By Kazuo KoвA. \\ Zoological Institute, Tokyo College of Literature and Science. \\ (Comm. by C. SaSaKi, M.I.A., April 13, 1936.)
}

The tropical freshwater crab, Geotelphusa dehaani (White) is widely spread in Japan proper. It occurs in torrents and rivulets in mountains and hills as well as in irrigation canals of rice fields.

Judging from the investigations that have been made on the specimens from various localities at my disposal, and also from the field observations made in the course of the present study, the breeding season of the present species in Japan proper, is from July to September. The eggs are extremely large, measuring 2.5 to $2.8 \mathrm{~mm}$ in diameter, and coloured cadmium yellow. So far as my observation goes, fiftythree is the maximum number of eggs possessed by one female. The egg is directly and firmly attached to the setae of endopodites of pleopods, contrary to the case of Astacura and marine Brachyura, in which the eggs are attached to the endopodites of pleopods by means of the twisted strands secreted by tegumental glands.

In length of the endopodite of the pleopod, the second and third pairs are nearly equal, the fourth come next, and the fifth the shortest. The number of the eggs attached to each of the second, third and fourth pleopods is greater than on the fifth, though it varies in different individuals even of the same size. Four examples are given in the following table.

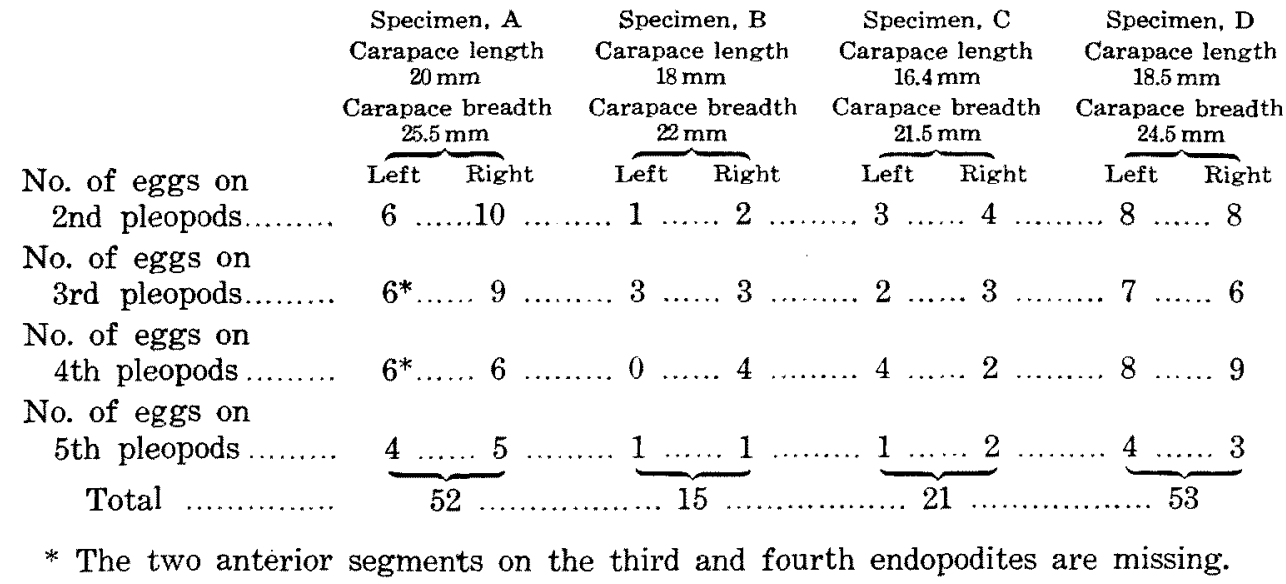

In the egg which contains an embryo ready to hatch out, the diameter measures $3.6 \mathrm{~mm}$. The embryo has the abdomen lying beneath the thorax and elongate-triangular in form. All the eggs borne by a female rarely hatch out at the same time. It is very common that a female carries three to five eggs contains embryos in advanced stage mixed with a number of eggs of very early stages.

In appearance the young crab just after hatching is essentially the 
same as the adult. The carapace is nearly quadrate in form, measuring $3.5 \mathrm{~mm}$ in length and $4.1 \mathrm{~mm}$ in breadth; the ratio being $1: 1.17$ (In the adult the ratio is $1: 1.32)$. The breadth between the outer orbital teeth in proportion to the breadth of the carapace is 0.85 ( 0.65 in the adult). The carapace is convex antero-posteriorly and flattened from side to side. The front is comparatively large, somewhat curved downward ; the anterior margin is bilobed and slightly concave in the middle portion; the antero-lateral margin is provided with denticles which are recognizable only with the microscope. In colour the carapace is pale mars yellow, the chelipeds and ambulatory legs are yellow ochre, and the dactyli white. The eyes are comparatively large; the cornea is coloured venetian red and the eye-stalk burnt sienna.

In the specimens with the carapace measuring $5 \mathrm{~mm}$ in length and $6 \mathrm{~mm}$ in breadth, the branchial region is more dilated laterally. The proportion of length to breadth of the carapace is $1: 1.2$ and the breadth between the outer orbital teeth in proportion to carapace breadth is 0.8 . Denticles on the antro-lateral margin are more conspicuous than in the earlier stage noted above.

In the more advanced stage with the carapace measuring $7.1 \mathrm{~mm}$ in length and $8.7 \mathrm{~mm}$ in breadth, the form of carapace is almost the same as that of the adult. The length in proportion to breadth is $1: 1.22$ and the breadth between the outer orbital teeth in proportion to carapace breadth is 0.77 . At each succeeding moult the transverse axis increases more markedly than the longitudinal axis.

The young are held between the abdomen and sternum of the female untill they are able to move about. If they are removed from the mother's body, and put into water, they do not hold their bodies in the manner customary to the adult. When they are successively fed for about a week, they begin to move about.

Many of the crabs belonging to Potamonidae do not metamorphose; some have a short period before metamorphosis. According to WillemoesSuhm (1875) and Mercanti ${ }^{1)}$ (1885) the young of Potamon fluviatile (Latreille) appear just like the adult. Lanchester (1901) has found that the young of Paratelphusa improvisa (Lanchester), carried by a female resemble closely the adult in the external feature. Rathbun (1904) recognizes the same fact in many species of Potamon, Paratelphusa, Platytelphusa, Pseudotelphusa and Potamonautes. F. Müller ${ }^{2)}$ (1892) also has shown that Trichodactylus fluviatilis Latreille does not metamorphose.

In addition to these facts on the development of the crabs of Potamonidae, I have been able to ascertain that Geotelphusa dehaani (White) hardly metamorphoses.

Contrary to these cases, Cardisoma guanhumi Latreille and Eriocheir sinensis H. Milne-Edwards which go into the sea during the breeding season, have small and very numerous eggs and the larvae hatch out in the zoëa-stage. It seems to me that the newly hatched stage in Geotelphusa dehaani (White) corresponds to "Bodenstadium" of Eriocheir sinensis H. Milne-Edwards. 
Hora, in his recent paper on the torrential fauna, gives an interesting remarks on the relation between the size of the egg of aquatic animals and its environment, that "The larvae from the large eggs are hatched out at a fairly advanced stage, so that they are capable of resisting the adverse effects of the environment to a certain degree. In an environment which is unfavourable for the free development of the young ones, the animals have responded by increasing the size of the egg."

The present species inhabits mountain and hill rivulets where it is difficult for the larva to lead a plankton life and the egg is extremely large and is hatched in a very advanced stage. Thus the facts observed in the development of Geotelphusa dehaani (White) seem to favour Hora's view.

Before closing I wish to express my sincere gratitude to Prof. Y. Okada for his kind advice given me in the course of this investigation. My thanks are also due to Prof. A. Oka, Prof. T. Komai and Dr. C. Moreira.

\section{Literature cited.}

Hora, S. L. (1930): Ecology, bionomics and evolution of the torrential fauna. Philos. Roy. Soc. London, (B), 218.

Koba, K. (1935): Preliminary notes on the distribution of Geotelphusa dehaani (White) in Japan. Bull. Biogeogr. Soc. Japan, 6.

Lanchester, W. F. (1901): On the Crustacea collected during the "Skeat" Expedition to the Malay Peninsula. Proc. Zool. Soc. London, 2.

Moreira, C. (1912): Embryologie du Cardisoma guanhumi Latr. Mém. Soc. Zool. France, 25.

Peters, N. und Panning, A. (1933): Die chinesische Wollhandkrabbe (Eriocheir sinensis H. Milne-Edwards) in Deutschland. Zool. Anz., Ergänzungsband zu 104.

Rathbun, M. J. (1904-06): Les crabes d'eau douce (Potamonidae). Nouv. Arch. Mus. Hist. Nat. Paris, 6, 7, 8.

Yonge, C. M. (1935): Origin and nature of the egg case in the Crustacea. Nature, 136. Willemoes-Suhm. R. v. (1875): On some Atlantic Crustacea from the "Challenger" Expedition. Trans. Linn. Soc. London, (II), 1. 